\title{
Thermophilic Actinomycetes from Hot Water Spring Capable of Producing Enzymes of Industrial Importance
}

\author{
Nazia Chaudhary, Shraddha Prabhu* \\ Department of Microbiology, Sophia College, Mumbai, Maharashtra-400026, India \\ chaudharynazia@gmail.com,*shraresearch@gmail.com
}

\begin{abstract}
With the increasing demand for industrial enzymes with novel properties, the production of enzymes tolerant to extreme conditions has also increased. Due to their unique macromolecular properties, thermophiles possess high metabolic rates, physically and chemically stable enzymes and higher end product yields than similar mesophilic species. Actinomycetes are bacteria which require minimal nutritional requirement for their growth and hence are preferred over thermophilic bacteria as source of industrial enzymes. In this study, thermophilic actinomycetes were isolated from hot water springs situated at Vajreshwari near Mumbai, Maharashtra and screened for the production of cellulase and amylase. Five isolates of thermophilic actinomyces obtained, tested positive for both amylolytic and cellulolytic activity. Two out of the five isolates were chosen for large scale production of the enzyme. The enzyme activity of the crude extract was determined using DNSA assay for reducing sugar. The optimum conditions for activity of amylase from isolate no. 4 were $55^{\circ} \mathrm{C}$ at $\mathrm{pH} 4.8$ and for cellulase were $55^{\circ} \mathrm{C}$ at $\mathrm{pH}$ 9. Amylase and cellulase with high stability and good activity at elevated temperature and acidic lalkaline conditions may find commercial applications in various fields such as such starch processing, food industries and detergents industries.
\end{abstract}

Keywords: Thermophile, Actinomycetes, Cellulase, Amylase, Hot springs

\section{INTRODUCTION}

Extremophiles have provided an interesting and challenging platform for researchers since the time of their discovery. Besides growth under the extreme conditions, their ability to produce industrially valuable compounds (such as enzymes, antibiotics etc.) has fascinated researchers. Among the various classes of microorganisms, thermophilic bacteria and actinomycetes are the organisms which produce variety of such compounds. In addition, cultivation of thermophiles at high temperature is technically and economically beneficial as it reduces risk of contamination and viscosity which leads to high degree of substrate solubility [1].

Enzyme-mediated reactions are attractive alternatives to tedious and expensive chemical methods. Due to ever increasing industrial growth, the demand for thermostable enzymes such as proteases, amylases, cellulases, lipases, xylanases and DNA polymerases has also increased [2]. Microbes are important sources of enzymes and are preferred over sources of plant and animal origin. More than $50 \%$ of the enzymes used in industrial processes are obtained from bacteria. [1]. Amylase is an important enzyme used in industries and accounts for $25 \%$ of the enzyme market. Thermostable $\alpha$ amylase have extensive commercial application in starch processing (stability at low $\mathrm{pH}$ ), brewing and sugar production, desizing in textile industries and in detergent manufacturing processes (stability at high $\mathrm{pH}$ ) $[3,4]$. Amylase with application in these industrial processes is characterized by being stable at $60-70^{\circ} \mathrm{C}$ and $\mathrm{pH}$ variation. Therefore, amylase extracted from thermophilic organisms could be useful for these applications.

Cellulose, the most abundant organic source of feed, fuel and chemicals, consists of glucose units linked by $\beta-1,4$-glycosidic bonds in a linear mode. In the current industrial processes, cellulolytic enzymes are employed in detergents, for color brightening and softening, stoning of jeans, pretreatment of cellulosic biomass and industrial wastes [5,6]. In order to attack the native water insoluble cellulose, thermostable cellulases active at high temperature and alkaline $\mathrm{pH}$ would be desired.

Actinomycetes consist of gram positive bacteria that show filamentous and branching growth pattern. They constitute a significant component of the microbial population in most soils and produce 
extracellular enzymes which can decompose various materials. Enzymes of Actinomyces are more attractive than enzymes from other sources because of their high stability and unusual substrate specificity. A wide array of enzymes and their products applied in biotechnological industries and biomedical fields has been reported from various genera of actinomycetes. In recent years, thermophilic actinomycetes have been subjected to intensive investigations in search for producers of new thermostable enzymes with activity at high temperature $\left(50-65^{\circ} \mathrm{C}\right)$ [7]. The constant search for novel enzymes with robust characteristics or applications in industrial processes, are key to profit growth [1]. To get enzymes with unique properties, screening programs for choosing rare actinomycetes are being adopted.

Actinomycetes found in extreme habitats have attracted considerable research interest due to their ability to produce novel products with huge commercial potential. However, many of the rare genera of actinomycetes have not been explored as prospective enzymes producer. Studies on unique ecological environments could yield enzymes that could be of great commercial importance in near future. In the present scenario, we focused attention on isolating thermophilic actinomycetes from natural habitat (hot spring), and then selected the best of isolates for the production of cellulase and amylase. We have also defined the optimum conditions for the activity of extracted enzymes through variations of $\mathrm{pH}$ and temperature.

\section{Materials ANd Methods}

\subsection{Collection and Processing of Sample from Hot Spring}

The Hot-springs were situated at Akoli, Vajreshwari (near Mumbai) in Maharashtra state from India. The temperature of the water in the springs ranged from $45^{\circ} \mathrm{C}$ to $62^{\circ} \mathrm{C}$ with $\mathrm{pH}$ of 7 to 8 . Following samples from four locations, (mainly from the area not tampered by human activities) were collected-

i. Water from Hot springs: $100 \mathrm{ml}$ in a sterile thermos.

ii. Scrapings of the inner wall of vents: $10 \mathrm{~g}$ in sterile petriplates.

iii. Bottom sediment: $10 \mathrm{~g}$ in sterile flasks.

Soil and sediment samples were kept at $55^{\circ} \mathrm{C}$ for 10 minutes [8]. The pretreated sample was used for the isolation of actinomycetes.

\subsection{Enrichment and Isolation of Actinomycetes}

Suspension of soil sample was made by mixing $1 \mathrm{~g}$ with $9 \mathrm{ml}$ saline and the soil was allowed to settle. The supernatant was collected and $1 \mathrm{ml}$ was inoculated in $10 \mathrm{ml}$ Norrinson and Ribbon broth and incubated at $45^{\circ} \mathrm{C}$ for $24 \mathrm{hr}$. A loopful of the enriched sample from the broth was isolated Kenknight and Munaier's Agar plate (pH 8). Water sample collected was directly inoculated on the Kenknight agar plate by spreading $0.1 \mathrm{ml}$ of each sample. These were then incubated at $45^{\circ} \mathrm{C}$ for a one week [9]. Colony characteristic of all Isolates were studied. Isolated colonies showing good growth were purified by repeated isolation on Kenknight and Munaier's Agar plates. Microscopic examination of the isolates was carried out using slide culture technique.

\subsection{Screening for Enzyme Activity}

Pure Isolates showing very good growth rate were screened for enzyme activity.

To detect amylase producers: Sterile $1 \%$ Starch agar plate was divided into four parts and four isolates were spot inoculated on each plate. The plates were then incubated for 72 hours at $45^{\circ} \mathrm{C}$. After incubation, the plates flooded with Gram's iodine solution. Amylase production was detected as zone of clearance on bluish purple background [10,11].

To detect cellulase producer: $0.1 \mathrm{ml}$ saline suspension of colony was added to $5 \mathrm{ml}$ Mac-beth's broth for enrichment of the Isolates. After incubation for five days at $45^{\circ} \mathrm{C}$, loopful of the broth was spot inoculated on cellulose agar plate and incubated for 72 hours at $45^{\circ} \mathrm{C}$. Cellulase Production was detected as zone of clearance after flooding the plates with solution $0.1 \%$ Congo red + iodine (1:1) solution $[12,13]$.

\subsection{Enzyme Production}

The isolates showing larger zone of clearance on both the plates were preserved on slants $\left(4{ }^{\circ} \mathrm{C}\right)$ and used for further experiments. Suspension of each Isolates was separately inoculated in $1 \%$ starch broth (amylase production) and $0.5 \%$ Carboxyl Methyl Cellulose broth (cellulase production) to get O.D 0.05 at $550 \mathrm{~nm}$. The organisms were grown on orbital shaker $(250 \mathrm{rpm} / \mathrm{min})$ at $45^{\circ} \mathrm{C}$ for 3 days in an incubator [14]. 


\subsection{Extraction of Amylase/ Cellulase}

Cells were removed by centrifugation at $3000 \mathrm{rpm}$ for 20 minutes. This crude (supernatant) enzyme was further used for assay.

\subsection{Enzyme Assay Protocol for Estimating Enzyme Activity}

\subsubsection{Assay for Amylase}

The assay system had $2 \mathrm{ml}$ of $1 \%$ starch with $1 \mathrm{ml}$ of phosphate buffer, $1 \mathrm{ml}$ of $0.5 \% \mathrm{NaCl}$ and $0.1 \mathrm{ml}$ of enzyme, which was incubated at $45^{\circ} \mathrm{C}$ for $20 \mathrm{mins}$ and $0.6 \mathrm{ml}$ of it was transferred to tubes containing $0.9 \mathrm{ml}$ of DNSA reagent [15]. The tube was then heated for $10 \mathrm{mins}$ in water bath $100^{\circ} \mathrm{C}$. They were cooled and $6 \mathrm{ml}$ of distilled water was added to it. Absorbance was measured at $530 \mathrm{~nm}$ on photoelectric colorimeter. This assay was done in duplicate for crude enzyme from each isolate.

Preparing standards:

The standards graph of quantitative estimation of maltose by DNSA method $(0.2$ to $2 \mathrm{mg} / \mathrm{ml}$ of Maltose) was prepared for determining the amount of product formed due to activity of amylase [16].

\subsubsection{Assay for Cellulase}

The assay system was prepared in the same manner as mentioned above for amylase except that 0.5 $\mathrm{ml}$ of $2 \%$ CM cellulose in $0.05 \mathrm{M}$ sodium citrate buffer $(\mathrm{pH} 4.8)$ was used as substrate with $0.5 \mathrm{~mL}$ of enzyme and incubation was done for 1 hour at $45^{\circ} \mathrm{C}$ [17].

Standard graph of quantitative estimation of glucose by DNSA method $(0.1$ to $1 \mathrm{mg} / \mathrm{ml})$ was prepared for determining the amount of product formed due to activity of cellulase [16].

Enzyme activity was calculated in terms of international units (IU) as $\mu \mathrm{mol}$ of product reducing sugars formed by $1 \mathrm{ml}$ of enzyme per minute [17].

\subsection{Effects of $\mathbf{p H}$ and Temperature on Activity}

\subsubsection{Effect of Temperature}

Optimum temperature is defined as the temperature at which the enzyme shows maximum activity. As the temperature increases the rate of reaction increases till the optimum is reached. At temperature higher than optimum, enzyme being protein gets denatured and hence there may be decrease or literally no activity. Effect of temperature was studied by performing the same assay system as mentioned above at incubation temperatures of $4^{\circ} \mathrm{C}, 28^{\circ} \mathrm{C}, 37^{\circ} \mathrm{C}, 55^{\circ} \mathrm{C}, 80^{\circ} \mathrm{C}$, and $100^{\circ} \mathrm{C}$.

\subsubsection{Effect of $p H$}

Enzymes have an optimum $\mathrm{pH}$ at which they show maximum activity. Change in $\mathrm{pH}$ results in decrease in activity due to change in configuration of the active site. In our study we tested activity of amylase and cellulase extracted from the isolates at different $\mathrm{pH}$ using different buffers such as acetate buffer ( $\mathrm{pH} \mathrm{4),} \mathrm{Sodium} \mathrm{citrate} \mathrm{buffer} \mathrm{(} \mathrm{pH} \mathrm{4.8),} \mathrm{Phosphate} \mathrm{buffer} \mathrm{(} \mathrm{pH} 7)$, Tris-amine methane buffer ( $\mathrm{pH}$ 9) and borate buffer ( $\mathrm{pH}$ 10.2). The assay system used was same as previously mentioned but at optimum temperature of $55^{\circ} \mathrm{C}$.

Enzyme activity at different $\mathrm{pH}$ and temperature was calculated in terms of amount of product formed by $1 \mathrm{ml}$ of enzyme per minute.

\section{RESUlTS AND DISCUSSION}

\subsection{Isolation and Identification of Actinomyces from Hot Spring}

The plates inoculated with samples from hot spring showed colonies with diverse morphologies. The colonies showing typical characteristics of actinomyces (i.e. small powdery dry, opaque) were selected and reisolated thrice on the Kenknight and Munaier's agar plates to obtain pure isolates (Table1). Twelve different types of isolates obtained, were maintained on Sterile Kenknight agar slants for further experiments. Sediment sample from hot spring, showed a good diversity of actinomycetes colonies while water sample had only two types. Several strains of actinomycetes have been previously reported from Hot-springs [18]. Thermophilic actinomycetes include the genera Streptomyces, Micromonospora, Actinomadura, Saccharomonospora and Thermoactinomyces [19]. 
Table1. Pure culture of Actinomyces species isolated from Hot spring

\begin{tabular}{|l|l|l|l|l|l|}
\hline $\begin{array}{l}\text { Colony } \\
\text { Characteristics }\end{array}$ & Isolate 4 & Isolate 5 & Isolate 6 & Isolate 7 & Isolate 8 \\
\hline $\begin{array}{l}\text { On K \& M Agar } \\
(\text { Grown for 72hr } \\
\text { At 45 c) }\end{array}$ & & & & & \\
& & & & & \\
& & & & & \\
\hline Size & 2mms & Pinpoint & 2mm & 3mms & 3mm \\
\hline Shape & Circular & Circular & Circular & Circular & Circular \\
\hline Margin & Entire & Entire & Entire & Entire & Entire \\
\hline Pigmentation & White & Bluish Green & Light Brown & Grey & White \\
\hline Opacity & Opaque & Opaque & Opaque & Opaque & Opaque \\
\hline Surface & Rough & Smooth & Rough & Smooth & Smooth \\
\hline Consistency & Powdery & Dry & Powdery & Soft & Soft \\
\hline Elevation & Flat & Flat & Flat & Centre Raised & Convex \\
\hline
\end{tabular}

Slide culture technique was done to observe the morphology and arrangement of the cells and spores (Figure 1c). The characteristics seemed to match the Streptomyces morphology, showing long mycelium with spores in different arrangements. Many plates had typical smell of wet soil, which are characteristic feature of Streptomyces [20]. Isolates were given numbers from 1 to 12 for easy identification. All of these isolates were screened for production of enzyme amylase and Cellulase.

\subsection{Screening for Amylase Producer}

On adding iodine to Starch agar plates with growth of isolates, a zone of clearance (on purple colour plate) was seen around Isolates 1,3,4,5,6,7,8 indicating that they produced amylase. Isolates 4, 7 and 8 showed bigger zone of clearance (Figure1a).

\subsection{Screening for Cellulase Producer}

On adding to Congo red solution to CMC agar plates with growth of isolates, a zone of clearance (on orange colour plate) was seen around isolates $2,4,5,6,7,8,11$. Since the medium contained cellulose as sole carbon source, the result of the test is a strong evident that cellulase was produced by isolates 2 , $4,5,6,7,8,11$. However the other isolates did not grow well. Here, again the Isolates 4, 7 and 8 showed distinct bigger zone of clearance than the rest (Figure1b).
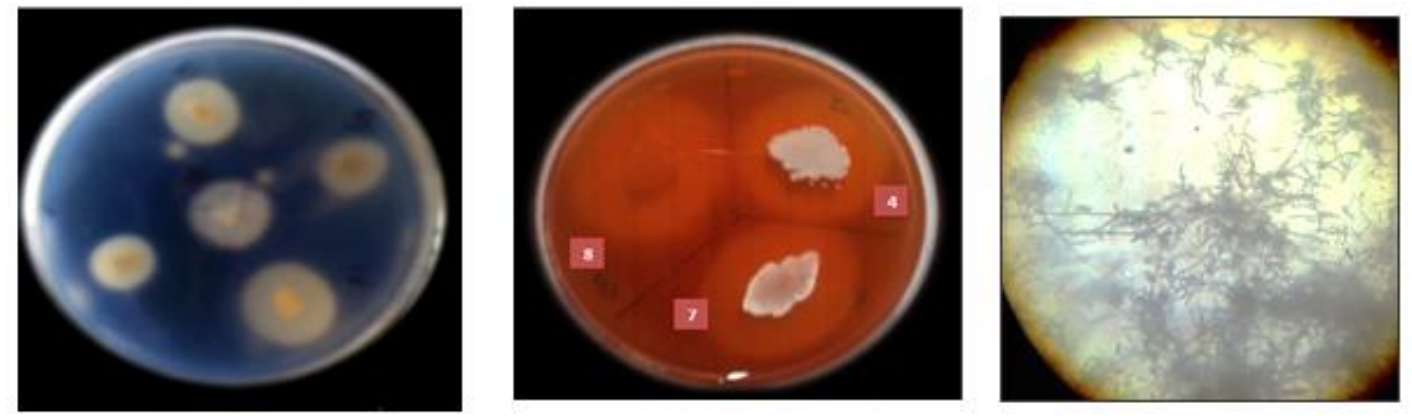

Figure1 a. Zone of starch hydrolysis produced by different isolates,

b. Zone of cellulose hydrolysis produced by some Actinomycetes Isolates

c. slide Culture observed under X45 showed filamentous Streptomyces.

All the isolates in the study were able to grow in the mesophilic range of temperatures but growth was better at higher temperature as seen by colony size.

\subsection{Production of Enzyme}

Results of the qualitative assay indicated that isolates 4, 5,6,7,8 produced both cellulase and amylase in detectable quantity. $5 \mathrm{ml}$ of the suspension (O.D ${ }_{530}$ 0.05) of each was separately inoculated in 100 $\mathrm{ml}$ modified Kenknight and Munaier's broth with starch or cellulose for large scale production of amylase and cellulase respectively. The production medium was incubated on shaker at $45^{\circ} \mathrm{C}$ for 3 days. Later the broth was centrifuged and the supernatant was used as crude enzyme. 


\subsection{Determination of Activity of Amylase and Cellulase from Actinomyces Isolate}

To check the amount of enzyme produced, quantitative estimation of enzyme by colorimetric method was done. The assay was performed in triplicate and mean values are shown here for comparison. The enzyme substrate tubes in assay for both amylase and cellulase showed much higher reading than blank in DNSA assay confirming that the enzymes were active. Amylase and cellulase activity of the crude extract was determined and compared (Table 2). Since isolate 4 and 7 gave better enzyme activity for both the enzymes; they were selected for further studies. Comparison of enzyme units indicated that Isolate no. 7 produced more amylase, whereas Isolate 4 produced more amount of cellulase as compared to others.

Table2. Comparison of enzyme production by the isolated species of Actinomyces from Hot spring

\begin{tabular}{|l|l|l|l|l|}
\hline \multirow{2}{*}{$\begin{array}{l}\text { Isolate } \\
\text { number }\end{array}$} & \multicolumn{2}{|l|}{ Zone of clearance $\{\mathbf{m m}\}$} & \multicolumn{2}{l|}{ Enzyme Activity in units/ml } \\
\cline { 2 - 5 } & on starch agar & on cellulose agar & Amylase & Cellulase \\
\hline 4 & 24.2 & 19.3 & $\mathbf{1 . 5}$ & $\mathbf{0 . 1 3}$ \\
\hline 5 & 10.6 & 15.6 & $\mathbf{0 . 4}$ & $\mathbf{0 . 0 7}$ \\
\hline 6 & 18.1 & 15.3 & $\mathbf{0 . 9}$ & $\mathbf{0 . 0 7}$ \\
\hline 7 & 25.3 & 18.6 & $\mathbf{1 . 6}$ & $\mathbf{0 . 1 1}$ \\
\hline 8 & 23.3 & 17.6 & $\mathbf{1 . 1}$ & $\mathbf{0 . 0 8}$ \\
\hline
\end{tabular}

\subsection{Effect of Important Parameters on the Amylase and Cellulase Activity}

The parameters studied were $\mathrm{pH}$ and temperature. Both the enzymes from both isolates showed considerable enzyme activity at wide range of $\mathrm{pH}$ (from 4 to 9 ) and temperature ( 28 to $80{ }^{\circ} \mathrm{C}$ ).

Amylase enzyme, from Isolate 4 showed maximum activity at $\mathrm{pH}$ of 4.8 , and from Isolate 7 at $\mathrm{pH}$ of 7. Cellulase enzyme from both isolate 4 and 7 showed maximum activity at $\mathrm{pH}$ of 9 . In assays to study effect of temperature on amylase and cellulase, maximum activity was seen at temperature of $55^{\circ} \mathrm{C}$ for both the isolates. Thus the optimum conditions for amylase from isolate 7 were $55^{\circ} \mathrm{C}$ at $\mathrm{pH} 7$ and for cellulose were $55^{\circ} \mathrm{C}$ at $\mathrm{pH}$ 9. The optimum conditions for amylase from isolate 4 were $55{ }^{\circ} \mathrm{C}$ at $\mathrm{pH} 4.8$ and for cellulase were $55^{\circ} \mathrm{C}$ at $\mathrm{pH} 9$ (Figure 2). These results demonstrate ability of the extracted enzymes to act under extreme environmental conditions (higher temperature and alkaline/ acidic $\mathrm{pH})$.
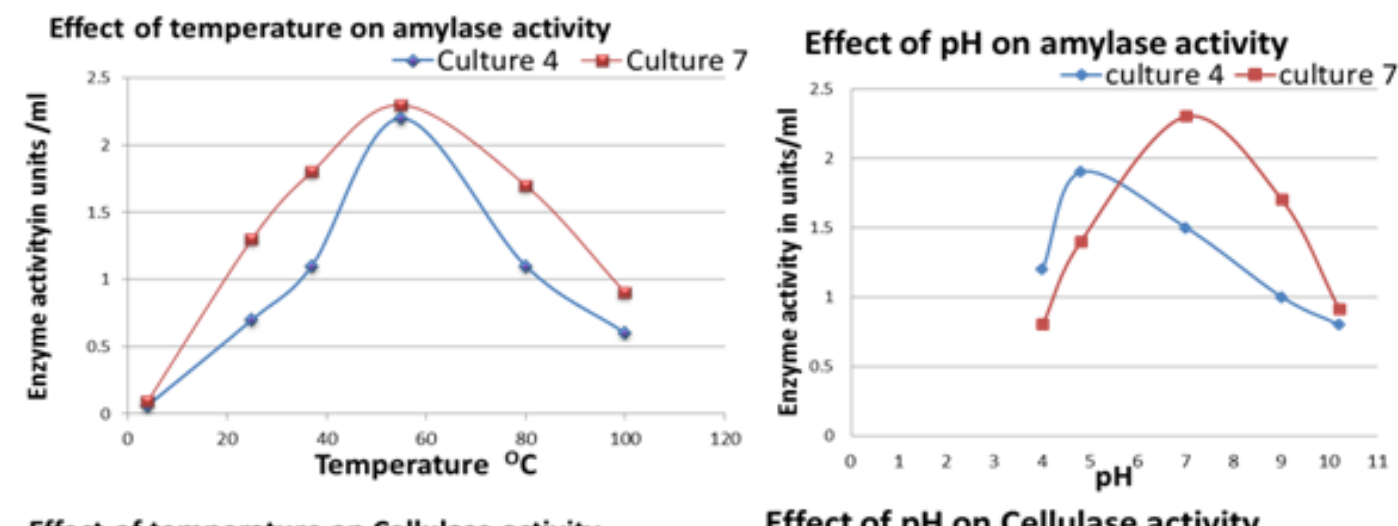

Effect of temperature on Cellulase activity
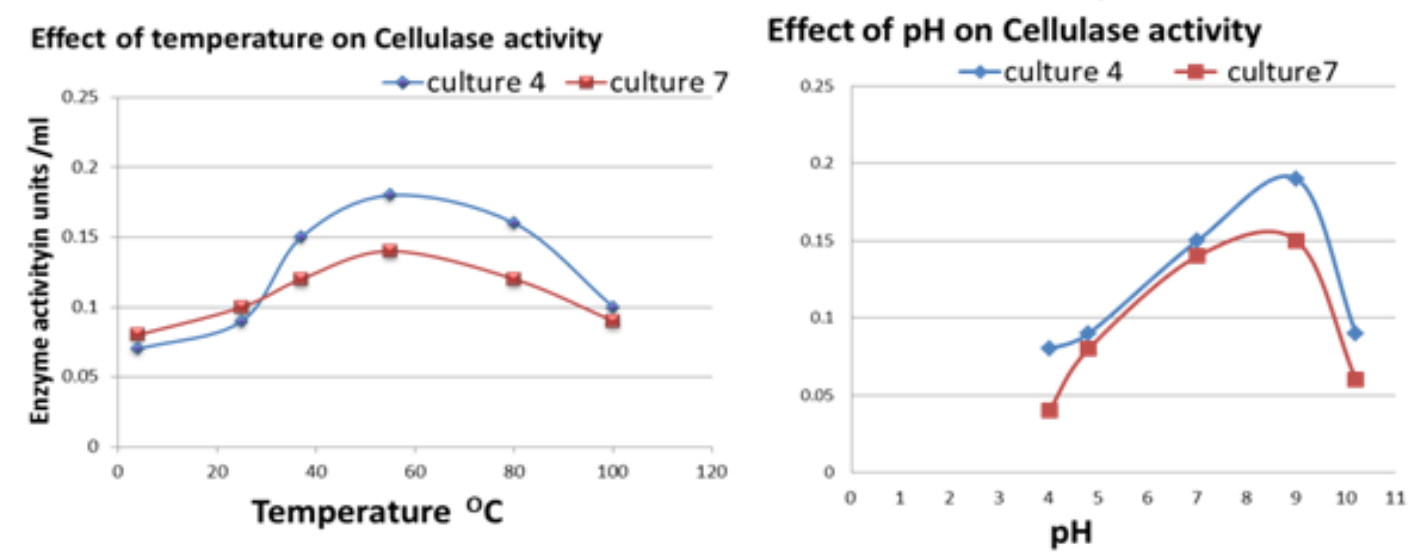

Figure2. Effect of $\mathrm{pH}$ and temperature on activity of amylase and cellulose from Isolate 4 and and isolate 7. 
Thermophilic and acidophilic amylases from Streptomyces have applications in bakery, brewing, and paper industries. The amylase from Thermobifida sp. was used to produce maltotriose from raw sago starch [21]. In the production process of sweeteners from starch, the temperature used is $50^{\circ} \mathrm{C}$ or more and $\mathrm{pH}$ close to 7 to prevent the browning effects and to reduce the viscosity of starch pastes. Hydrolysis carried out at higher temperature also minimizes polymerization of $\mathrm{D}$-glucose to isomaltose [22]. Thermostable amylases like the one extracted from Isolate7 are desired for this purpose as their use would also minimize contamination risk and reduce the reaction time. Cellulaseproducing Actinomycetes have potential applications in converting cellulose into fermentable sugars fit for human consumption and in biofuel generation [1]. Cellulases from isolate 4 and 7, showing activity at high temperature and alkaline $\mathrm{pH}$ would be useful for this purpose.

It is evident from the results that the isolated species of Streptomyces were capable of producing considerable amount of both amylase and cellulase with temperature optimum at $55^{\circ} \mathrm{C}$. The yield obtained can be increased by using nutrient rich medium for growth instead of a defined medium. Utilization of such enzymes is, however often limited by the cost of production. More studies need to be done to optimize the production cost of these important enzymes from actinomyces isolates. Large scale cellulase production has been carried out on cheap substrates like rice and wheat straw [23] and fruit peels [24]. Growing the organisms on cheaper substrates or agricultural wastes will help in bringing down the cost. Streptomyces are now being recognized as the best known producers of array enzymes like isomerase, amylase, cellulase, lipase, protease, pectinase, keratinase, L-asparginase, chitinases, and xylanases [25]. Several genes encoding extracellular enzymes have been cloned from Streptomyces species [26]. Recombinant enzymes with new characteristics and high productivity may help in lowering cost of production hence can also be the subject of future studies.

\section{CONClusion}

In the present study, we successfully isolated Actinomyces species from hot water spring which produce remarkable amount of thermostable amylase and cellulase. The interesting observation made in this study was the amylase exhibiting maximum activity at acidic $\mathrm{pH}$ and cellulases with optimum $\mathrm{pH}$ in the alkaline range. Amylase and Cellulase with such properties will be of great commercial importance and can be considered as probable candidates for industrial processes which use diverse range of $\mathrm{pH}$ and temperatures in a large number of fields such as food, dairy, pharmaceutical, detergent, textile, and cosmetic industries. Thermophilic actinomycetes play an important role in habitats where decomposition of organic matter takes place at elevated temperatures and under aerobic conditions. Using these isolates for direct hydrolysis agro-industrial waste and in biofuel generation also seems a promising strategy.

\section{ACKNOWLEDGMENT}

The authors wish to thank Ms. Pearl Rodrigues for providing help during sample collection and microbiological work. The authors are also grateful to the staff of the Department of microbiology, Sophia College for their generous support for completion of this project.

\section{REFERENCES}

[1] P. Turner, G. Mamo, Eva N. Karlsson, Potential And Utilization Of Thermophiles And Thermostable Enzymes in Biorefining, Microbial Cell factories. 6:9 (2007) DOI: 10.1186/14752859-6-9.

[2] Divya Prakash et al., Actinomycetes: A Repertory of Green Catalysts with a Potential Revenue Resource, BioMed Research International(2013), Article ID 264020,8 pages DOI: $10.1155 / 2013 / 264020$

[3] Leveque E, Janecek S, Haye B, Belarbi A. Thermophilic archaeal amylolytic enzymes, Enzyme Microb. Technol. 26: 3-14(2000).

[4] Saxena RK, Dutt K, Agarwall L, Nayyar P. A Highly Thermostable And Alkaline Amylase From A Bacillus Sp. PN5, Biores. Technol. 98: 260-265 (2007).

[5] Sukumaran Et Al: Microbial Cellulases: Production, Applications And Challenges. Journal of Scientific \& Industrial Research. 64(1) pp. 832-844, (2005).

[6] H. D. Jang and K. S. Chang, "Thermostable cellulases from Streptomyces sp.: scale-up production in a 50-1 fermenter," Biotechnology Letters, 27(4), pp. 239-242, (2005). 
[7] Allen, M.J. Hartman, P.A. Amylolytic Isoenzymes Of Thermoactinomyces Vulgaris. Journal of Bacteriology, 109(1) P.452-454 (1972).

[8] D. Divya Teja, Sri Devi, N. Harsha, S. Satya Vishala and P. K. S. Lakshmi., Production of LGlutaminase From Marine Ecosystems And Optimal Conditions, International Journal Of Advanced Research. 2(1), 485-491(2014).

[9] Ronald Atlas. Handbook of Microbiological Media, Fourth Edition (2010) page 895.

[10] Jeffrey, L. S. H., Isolation, characterization and identification of actinomycetes from agriculture soils at Semongok, African Journal of Biotechnology. 7 (20), 3697-3702, (2008).

[11] M.J. Kuo, P.A. Hartman., Isolation of Amylolytic Strains of Thermoactinomycetes Vulgaris And Production of Thermophilic Actinomycetes Amylases. J. Bacteriol 92(3),723-726 (1966).

[12] Pinky Prasad, Sheila Bedi, Tanuja Singh, In vitro Cellulose Rich Organic Material Degradation by Cellulolytic Streptomyces albospinus (MTCC 8768), Malaysian Journal of Microbiology. 8(3), 164-169 (2012).

[13] Yugal Kishore Mohanta., Isolation of Cellulose-Degrading Actinomycetes and Evaluation of their Cellulolytic Potential, Bioengineering and Bioscience. 2(1),1-5 (2014).

[14] H. Ariffin, N. Abdullah, M.S. Umi Kalsom, Y. Shirai, M.A. Hassan., Production And Characterization of Cellulase by Bacillus Pumilus, International Journal of Engineering and Technology. 3(1), 47-53(2006).

[15] É. R. d. Santos, Z. N. Santos Teles, Núria M. Campos, Jacinto de Souza, Production of $\alpha$ amylase from Streptomyces sp. SLBA-08 strain using agro-industrial by-products, Braz. arch. biol. technol. 55 (5), (2012).

[16] G. L. Miller. Use of dinitrosalicylic acid reagent for determination of reducing sugar, Analytical Chemistry. 31(3), 426-428, (1959).

[17] K. Ghose. Measurement of cellulase activity, Pure and Applied Chemistry. 59(1), 257-268, (1987).

[18] Pednekar P, Jain R, Mahajan G. Anti-infective Potential of Hot-spring Bacteria. Journal of Global Infectious Diseases. 3(3), 241-245(2011). doi:10.4103/0974-777X.83529.

[19] Mukesh Sharma. Actinomycetes: Source, Identification, and Their Applications, Int. J. Curr. Microbiol. App. Sci. 3(2), 801-832(2014)

[20] Alexander, M. Introduction to soil microbiology, 2nd éd. 1977. Krieger Publishing Company, pp 467.

[21] C.H. Yang, W.H. Liu., Purification and Properties of Maltotriose producing $\alpha$-Amylase From Thermobifida Fusca, Enzyme and Microbial Technology.35(1), 254-260, (2004)

[22] Pandey A., P. Nigam, C.R. Soccol, V.T. Soccol, D. Singh, R. Mohan., Advances in microbial amylases, Biotechnol. Appl. Biochem. 31(1) 135-152(2000).

[23] N. A. El-Sersy, H. Abd-Elnaby, G. M. Abou-Elela, H. A. H. Ibrahim, N. M. K. El-Toukhy, Optimization, economization and characterization of cellulase produced by marine Streptomyces ruber, African Journal of Biotechnology. 9(38), 6355-6364 (2010).

[24] R. K. Rathan , M. Ambili, Cellulase Enzyme Production by Streptomyces Sp. Using Fruit Waste as Substrate, Australian Journal of Basic and Applied Sciences. 5(12), 1114-1118 (2011).

[25] C. Narasaiah, V. Leelavathi, A. K. Manne, G.Swapna, M. Paul. M. Dasu., Screening of Streptomyces Albus CN-4 for enzyme Production and Optimization of L-Asparaginase, International Journal of Scientific and Research Publications. 5(3), (2015).

[26] A. Amore, O. Pepe, V. Ventorino, L. Birolo, C. Giangrande, Cloning And Recombinant Expression Of a Cellulase From The Cellulolytic Strain Streptomyces Sp. G12 Isolated From Compost, Microbial Cell Factories.11:164 (2012) DOI: 10.1186/1475-2859-11-164 